\title{
New mammalian and avian records from the late Eocene La Meseta and Submeseta Formations of Seymour Island, Antarctica
}

\author{
Sarah N. Davis ${ }^{\text {Corresp., } 1}$, Christopher R. Torres ${ }^{2}$, Grace M. Musser ${ }^{1}$, James V. Proffitt ${ }^{3}$, Nicholas M.A. Crouch ${ }^{1}$, \\ Ernest L. Lundelius ${ }^{1}$, Matthew C. Lamanna ${ }^{4}$, Julia A. Clarke ${ }^{1}$ \\ ${ }^{1}$ Department of Geological Sciences, Jackson School of Geosciences, The University of Texas at Austin, Austin, TX, United States \\ 2 Department of Integrated Biology, The University of Texas at Austin, Austin, TX, United States \\ ${ }^{3}$ School of Medicine, The University of Missouri, Columbia, Missouri, United States \\ 4 Section of Vertebrate Paleontology, Carnegie Museum of Natural History, Pittsburgh, Pennsylvania, United States of America \\ Corresponding Author: Sarah N. Davis \\ Email address: sdavis6@utexas.edu
}

The middle-late Eocene of Antarctica was characterized by dramatic change as the continent became isolated from the other southern landmasses and the Antarctic Circumpolar Current formed. These events were crucial to the formation of the permanent Antarctic ice cap, affecting both regional and global climate change. Our best insight into how life in the high latitudes responded to this climatic shift is provided by the fossil record from Seymour Island, near the eastern coast of the Antarctic Peninsula. While extensive collections have been made from the La Meseta and Submeseta Formations of this island, few avian taxa other than penguins have been described and postcranial mammalian remains have been scarce. Here, we report new fossils from Seymour Island collected by the Antarctic Peninsula Paleontology Project. These include a mammalian metapodial referred to Xenarthra and avian material including a partial tarsometatarsus referred to Gruiformes (cranes, rails, and allies). Penguin fossils (Sphenisciformes) continue to be most abundant in new collections from these deposits. We report several penguin remains including a large spear-like mandible preserving the symphysis, a nearly complete tarsometatarsus with similarities to the large penguin clade Palaeeudyptes but possibly representing a new species, and two small partial tarsometatarsi belonging to the genus Delphinornis. These findings expand our view of Eocene vertebrate faunas on Antarctica. Specifically, the new remains referred to Gruiformes and Xenarthra provide support for previously proposed, but contentious, earliest occurrence records of these clades on the continent. 


\section{New mammalian and avian records from the late Eocene La}

\section{Meseta and Submeseta Formations of Seymour Island,}

\section{Antarctica}

4 Sarah N. Davis, ${ }^{1}$ Christopher R. Torres,${ }^{2}$ Grace M. Musser, ${ }^{1}$ James V. Proffitt,, 3 Nicholas M. A.

5 Crouch, ${ }^{1}$ Ernest L. Lundelius, ${ }^{1}$ Matthew C. Lamanna, ${ }^{4}$ and Julia A. Clarke ${ }^{1}$

7 1. Department of Geological Sciences, Jackson School of Geosciences, The University of Texas

8 at Austin, Austin, Texas 78712, USA;

9 2. Department of Integrative Biology, The University of Texas at Austin, Austin, Texas 78712 ,

10 USA;

11 3. School of Medicine, The University of Missouri, Columbia, Missouri 65212, USA;

12 4. Section of Vertebrate Paleontology, Carnegie Museum of Natural History, 4400 Forbes

13 Avenue, Pittsburgh, Pennsylvania 15213, USA

15 Corresponding Author:

16 Sarah Davis $^{1}$

17 Department of Geological Sciences, Jackson School of Geosciences, The University of Texas

18 at Austin, Austin, Texas 78712, USA

19 Email address: sdavis6@utexas.edu 


\section{Abstract}

23 The middle-late Eocene of Antarctica was characterized by dramatic change as the continent

24 became isolated from the other southern landmasses and the Antarctic Circumpolar Current

25 formed. These events were crucial to the formation of the permanent Antarctic ice cap, affecting

26 both regional and global climate change. Our best insight into how life in the high latitudes

27 responded to this climatic shift is provided by the fossil record from Seymour Island, near the 28 eastern coast of the Antarctic Peninsula. While extensive collections have been made from the

29 La Meseta and Submeseta Formations of this island, few avian taxa other than penguins have

30 been described and postcranial mammalian remains have been scarce. Here, we report new

31 fossils from Seymour Island collected by the Antarctic Peninsula Paleontology Project. These

32 include a mammalian metapodial referred to Xenarthra and avian material including a partial

33 tarsometatarsus referred to Gruiformes (cranes, rails, and allies). Penguin fossils

34 (Sphenisciformes) continue to be most abundant in new collections from these deposits. We

35 report several penguin remains including a large spear-like mandible preserving the symphysis, a

36 nearly complete tarsometatarsus with similarities to the large penguin clade Palaeeudyptes but

37 possibly representing a new species, and two small partial tarsometatarsi belonging to the genus

38 Delphinornis. These findings expand our view of Eocene vertebrate faunas on Antarctica.

39 Specifically, the new remains referred to Gruiformes and Xenarthra provide support for

40 previously proposed, but contentious, earliest occurrence records of these clades on the

41 continent. 


\section{Introduction}

The Southern Hemisphere biota has been profoundly influenced by Mesozoic-Cenozoic continental breakup and climatic change. Before its fragmentation, the supercontinent Gondwana facilitated dispersal of terrestrial organisms between now-separated southern landmasses (Keast, 1972; Cracraft, 1973; Ali and Krause, 2011; Claramunt and Cracraft, 2015). Early discoveries suggest that Antarctica was central to this pattern of terrestrial movement, acting as a bridge between what is now South America and Australia (Woodburne and Zinsmeister, 1984; Zinsmeister, 1986). This widespread dispersal ended with the final breakup of Gondwana (Reguero et al., 2014, and reviewed by Torsvik and Cocks, 2013). Through the last part of this breakup, the Antarctic climate shifted from being warm and seasonally wet to increased periods of ice cover by the early to middle Eocene (Poole et al., 2001; Ivany et al., 2011; Jacques et al., 2014); by the earliest Oligocene ( 33.9 Ma) Antarctica experienced complete glaciation (Zachos et al., 2001; Birkenmajer et al., 2004; Ivany et al., 2006; Barker et al., 2007).

Insights into how the Antarctic biota was shaped by tectonic and climatic shifts have come from the Upper Eocene La Meseta and Submeseta Formations on Seymour Island (Marambio Island), the best-studied fossil vertebrate fauna from Antarctica (e.g., Reguero et al., 2002; 2014). This assemblage has been proposed to most closely resemble contemporaneous faunas from Patagonia (Reguero et al., 2002) which were separated from what is now the Antarctic Peninsula by the flooding of the Weddellian Isthmus at the end of the Paleocene (Eagles and Jokat, 2014; Reguero et al., 2014). The fossil record of the La Meseta and Submeseta Formations are famously dominated by stem penguins, including some of the tallest penguins that ever lived (Tambussi et al., 2006; Jadwiszczak, 2006; Tambussi and Acosta 
68 Hospitaleche, 2007; Jadwiszczak et al., 2013; Acosta Hospitaleche, 2014; Acosta Hospitaleche

69 and Reguero, 2014; Jadwiszczak and Mörs, 2019). The non-penguin vertebrate fossil record

70 mostly comprises isolated teeth and bones representing an array of marsupial, gondwanathere,

71 ungulate, cetacean, and other eutherian mammals as well as a possible non-therian dryolestoid

72 (see Woodburne and Zinsmeister, 1982; Marenssi et al., 1994; Reguero et al., 2002; Reguero and

73 Gasparini, 2006; Case, 2006; Martinelli et all., 2014; Buono et al. 2016; Gelfo et al. 2017; Gelfo

74 et al. 2019) as well as non-penguin birds (e.g., Tambussi and Acosta Hospitaleche, 2007;

75 Jadwiszczak et al., 2008; Cenizo, 2012; Tambussi and Degrange, 2013; Cenizo et al., 2015;

76 Acosta Hospitaleche and Gelfo, 2017; and reviewed in Acosta Hospitaleche et al., 2019a). Here

77 we report additional mammalian and avian specimens recovered from Antarctica by the 2016

78 Antarctic Paleontology Project (AP3), including a gruoid and a xenarthran fossil, and discuss

79 their biogeographic implications.

80

\section{Geologic setting}

82 The fossils here described were collected from Eocene deposits on Seymour Island. The island is

83 located approximately $100 \mathrm{~km}$ east of the Antarctic Peninsula in the James Ross Basin and

84 contains fossiliferous marine sedimentary units ranging from Late Cretaceous to Late Eocene/

85 earliest Oligocene in age (Sadler, 1988; Marenssi et al., 1998; Montes et al., 2013). These

86 deposits can be divided into the Marambio Group (Santonian-Danian; Marenssi et al., 1998) and

87 the unconformably overlaying Seymour Island Group (Paleogene; Sadler, 1988; Marenssi et al

88 1998). The Marambio Group is made up of the Santa Marta (Santonian to Campanian), Snow

89 Hill Island (Campanian to Maastrichtian), López de Bertodano (Maastrichtian to Danian), and

90 Sobral (Danian) formations, while the Seymour Island group includes the Cross Valley (upper 
91 Paleocene), La Meseta (Eocene), and Submeseta (Upper Eocene to earliest Oligocene)

92 Formations (Sadler, 1988; Bowman et al., 2016; Montes et al., 2013).

The La Meseta Formation is predominantly made up of mudstones and sandstones and is

94 interbedded by conglomerates (Marenssi et al., 1998). The formation was divided into numbered

95 informal units called TELMs (Tertiary Eocene La Meseta) 1-7 by Sadler (1988). These units

96 were later divided into allomembers (from bottom to top: Valle de Las Focas, Acantilados I,

97 Acantilados II, Campamento, Cucullaea I, Cucullaea II, and Submeseta), with the Submeseta

98 Allomember (comprising the upper portion of TELM 6 and all of TELM 7) later reassigned as

99 the Submeseta Formation (Marensi et al., 1998; Montes et al., 2013). The Submeseta Formation

100 represents the latest Eocene (Priabonian) to earliest Oligocene, between 45.9 and $33 \mathrm{Ma}$

101 (Marenssi et al., 1998; Marenssi, 2006; Montes et al., 2013). This unit is composed

102 predominantly of fine sandstones and mudstones from a shallow marine environment, but may

103 reflect a sea level rise towards the top of the section (Marenssi et al., 2002; Marenssi, 2006;

104 Montes et al., 2013). The Submeseta Formation itself has been divided into three units defined

105 by their boundary discontinuities: the lower Submeseta I, middle Submeseta II, and upper

106 Submesta II Allomembers (Marenssi et al., 1998; Montes et al., 2013).

107 Fossils were surface collected at four localities on the northeastern end of Seymour Island

108 (Fig. 1) from cross- bedded fine sandstone units, interpreted as shallow marine or estuarine

109 environments. A mammalian metacarpal was collected from locality S124, located in the

110 Cucullaea I Allomember of the La Meseta Formation (52.8-49 Ma). A penguin mandible was

111 collected from locality S074, within Cucullaea II of the La Meseta Formation (49-45.9 Ma), and

112 all tarsometatarsi were collected from Submeseta I of the Submeseta Formation (45-41 Ma) at

113 localities S123 and S117/122. 
115 Illinois, USA; IB/P/B, Andrzej Myrcha University Museum of Nature, Białystok, Poland; MLP,

116 Museo de La Plata, La Plata, Buenos Aires Province, Argentina; TMM, Jackson School of

117 Geosciences, Vertebrate Paleontology Laboratory, Austin, Texas, USA.

118

119 Systematic Paleontology

120

121

122

123

124

125

MAMMALIA Linnaeus, 1758

EUTHERIA Gill, 1872

XENARTHRA Cope, 1889

Gen. et sp. indet.

(Fig. 2, Supplemental Fig. 1)

126

127 Material - TMM 44190-1, left metacarpal II.

128

Locality - S124, Seymour Island, Antarctic Peninsula.

129 Formation/Age - Cucullaea I Allomember (TELM 4), La Meseta Formation, late Eocene.

130 Description - TMM 44190-1 is weathered and missing the distal epiphysis. The distal

131 surface (Fig. 2F) is extensively pitted and shows no sign of breakage, indicating that TMM

132 44190-1 likely belonged to a juvenile individual. It has a maximum proximodistal length of 33

$133 \mathrm{~mm}$ as preserved and a maximum mediolateral width of $21 \mathrm{~mm}$ at both the proximal and distal

134 ends.

135 In medial view, the articular facet for what could be the metacarpal-carpal complex or for

136 metacarpal I is sharply-defined, forming the proximal part of the palmar margin and projecting 
137 well-palmarly of the rest of this margin (Fig. 2A). The remainder of the medial face is marked by

138 two rugosities: one at the proximopalmar part and the other across the entire distal half (Fig. 2A).

139 These rugosities are separated by a smooth sulcus, resulting in a notched medial margin in

140 dorsal/plantar views (Fig. 2C-D). In lateral view, an articular facet, potentially for metacarpal III,

141 is rugose and worn (Fig. 2B). Due to the bone being hourglass-shaped in medial and lateral

142 views (Fig. 2A-B) but sub-rectangular in dorsal and palmar views (Fig. 2C-D), the latter faces

143 are broadly concave and saddle-shaped. The articular face for the ?trapezoid carpal is triangular

144 with sharply-defined medial and dorsal margins, and slopes slightly towards the medial edge

145 (Fig. 2E).

146 Comparisons - The majority of mammal fossils from the Eocene of Seymour Island

147 comprise teeth and isolated postcranial material of marsupials (Woodburne and Zinsmeister,

148 1982; Goin and Carlini, 1995; Goin et al., 1999; Goin et al., 2007; Chornogubsky et al., 2009;

149 Goin et al., 2018), Astrapotheria (Bond et al., 2011), Gondwanatheria (Goin et al., 2006; Gelfo et

150 al., 2015), notoungulates (Litopterna, Bond et al., 2006; Gelfo et al., 2015), and potential

151 xenarthrans (Marenssi et al., 1994; Vizcaíno and Scillato-Yané, 1995). These mammalian

152 records were most recently reviewed by Gelfo et al. (2019). Given the juvenile status and

153 isolated nature of TMM 44190-2, as well as the relative paucity of described mammalian

154 metacarpals from this time period, it is difficult to make comparisons with other

155 contemporaneous fossils. We therefore limit detailed comparison to clades known from Seymour

156 Island, except for gondwanatheres for which no carpal material has been described.

157 The metacarpals of Paleogene marsupials are more elongate and gracile than TMM

158 44190-1, with more rounded proximal ends. Metacarpal II specifically shows less prominent

159 articular facets for metacarpal III compared to the new fossil (see Forasiepi et al., 2014: fig. 12a- 
160 c). In Astrapotheres, the second metacarpal is subrectangular and apparently dorso-palmarly

161 compressed while widening distally, but has a prominent ridge along the lateral side that is not

162 seen in the new fossil (Scott, 1937: Plate V, fig. 1). In ?Parastrapotherium the proximal facet

163 appears somewhat flattened similar to the condition in TMM 44190-1, but the metacarpal

164 contains a shallow pit along the medial surface not seen in the new fossil. The metacarpal also

165 does not taper as dramatically towards the midpoint of the element (Scott 1909: fig. 6). However,

166 there are no detailed illustrations of individual metacarpals of ?Parastrapotherium, and so these

167 apparent similarities are difficult to further assess. Notoungulate metacarpals are more elongated

168 than the new fossil, have a saddle-shaped articulation for the trapezoid, and have more points of

169 articulation with the carpals than is seen on TMM 44190-1 (Shockey and Flynn, 2007: fig. 4).

170 Overall the robustness and proportions of TMM 44190-1 are most consistent with the

171 metacarpals of xenarthrans, though it does not have conspicuous affinities with a particular

172 subclade. Within Cingulata (glyptodonts, armadillos), the metacarpals and metatarsals are most

173 often figured in articulated posture which complicates comparisons, especially of their articular

174 facets (see Gillette and Ray, 1981; Fernicola et al., 2018; Cuadrelli et al., 2019; Scott, 1903-

175 1905). The second metacarpals of the North American Glyptotherum texanum and South

176 American Glyptodon reticulatus are of similar proportion and share the hourglass configuration

177 in lateral and medial views as TMM 44190-1, though they have less dorso-palmar tapering

178 towards the center of the diaphysis than is seen in the new fossil (Gillette and Ray, 1981: fig. 33;

179 Cuadrelli et al., 2019: fig. 5c). The articulation for the trapezoid in both taxa is dramatically 180 concave, in contrast to the flat, triangular surface in TMM 44190-1, and there are two points of

181 contact along the proximal end between metacarpals II and III rather than one. The articular

182 surface for metacarpal III in the Miocene armadillo relative Proeutatus is similarly shaped to that 
183 of TMM 44190-1, though it is only figured as articulated and this cannot be confirmed (Scott,

184 1903-1905: plate XIV fig. 4 and 5). The Oligocene genus Peltephilus is most similar amongst

185 representative of the cingulates to the new fossil, though it appears longer (Scott, 1903-1905:

186 plate XVI fig. 11). The dorsal edge of the articular surface for the trapezoid appears similarly flat

187 and sloped as in TMM 44190-1, and the facets for metacarpal III and the metacarpal-carpal

188 complex appear proportional to the new fossil as well (Scott, 1903-1905: plate XVI fig. 11).

189 However towards the distal end the metacarpal tapers in a way that TMM 44190-1 would not,

190 even if the missing epiphysis were present.

191 The new fossil also shares some features seen in Pilosa (anteaters, sloths). Although no

192 metacarpal IIs have been recovered for Paleogene folivorans (sloths), there are similarities with

193 the metacarpals of younger sloth taxa. The overall shape of the metacarpal resembles that of

194 adult specimens of Megalonyx spp. (TMM 30967-1845; see also De Iuliis and Cartelle, 1999:

195 fig. 7B), Hapalops spp. (Stock, 1925: fig. 23), and Eucholeops spp. (De Iuliss et al., 2014: fig. 9

196 and 10). TMM 44190-1 is more robust than the metacarpal II of some other xenarthrans such as

197 Thalassocnus (Amson et al., 2015) and Mionothropus cartellei (De Iuliis et al., 2011: fig. 11),

198 but more closely matches the proportions of Pleistocene ground-dwelling taxa such as

199 Megatherium urbinai (Pujos and Salas, 2004). At the distal end of the metacarpal, TMM 44190-

2001 is more mediolaterally wide than it is dorsopalmarly tall, a proportion that does not match other

201 measured sloth metacarpal (e.g. see Eucholeops; De Iuliis et al., 2014; Amson et al., 2017:

202 character 20). The ratio of the proximodistal length to dorsopalmar depth for TMM 44190-1 is

203 1.57, which falls far below most values reported for other sloth taxa and near Glossotherium,

204 well within the range considered stout (Amson et al. 2017: Appendix S3). The trapezoid facet is

205 sub-planar, similar to that of Pseudolestodon hexaspondylus and Simomylodon uccasamamensis 
206 (Haro et al., 2017: character 334). However, this is different than the concave facets seen in other

207 sloths such as Eremotherium eomigrans (De Iuliis and Cartelle, 1999: fig. 10c) and Thalassocnus

208 (Amson et al., 2015: fig 34 and 35). In TMM 44190-1, the articular facet for the metacarpal-

209 carpal complex does not extend distally to the midpoint of the shaft as in younger forms such as

210 Hapalops (Miocene) and Nothrotherium (Pleistocene, Stock, 1925). The new fossil is also

211 lacking facets seen in some sloth taxa, such as one for the magnum as in E. eomigrans,

212 Megatherium americanum, and Thalassocnus (De Iuliis and Cartelle, 1999: fig. 7; Amson et al.,

213 2015: fig. 35; see Amson et al., 2017: character 16) or the unciform as seen in Scelidotherium

214 (Cuenca Anaya, 1995: pp 176). It is unclear if the rugose surface texture along the medial face is

215 consistent with its juvenile status or could be due to a closely-appressed digit I (as in for example

216 Mionothropus; De Iuliis et al., 2011). There are no figured second metacarpals for extinct

217 Vermilingua (anteaters), but in extant anteaters the second metacarpals are long and thin and

218 quite different from the new fossil (Beddard 1902: fig. 95; Orr, 2005: fig. 4b).

219 Eocene in age, and therefore close to the estimated early radiation of xenarthran groups,

220 the likelihood of a single metacarpal having a diagnostic characteristic of one particular

221 xenarthran subclade may be expected to be low. The fossil shows several features seen in extinct

222 members of both Pilosa and Cingulata, and particularly with early diverging examples such as

223 Peltephilus. While these similarities suggest TMM 44190-1 is a xenarthran, further subclade

224 attribution is not possible.

225

226

227

228 
AVES Linnaeus, 1758

NEOGNATHAE Pycraft, 1900

Gen. et sp. indet.

Material - TMM 44189-2, distal end of left tarsometatarsus.

237

Locality - S123, Seymour Island, Antarctic Peninsula.

Formation/Age - Submeseta Allomember I (TELM 7), Submeseta Formation, late Eocene.

Description - TMM 44189-2 preserves the bases of trochleae II-IV as well as the dorsal and plantar openings of the distal vascular foramen. The maximum mediolateral width as preserved is $25 \mathrm{~mm}$ (Fig. 3). The distal vascular foramen is proximodistally elongate in dorsal and plantar views (Fig. 3A-B), and the dorsal opening of the foramen is set in a deep sulcus (Fig. 3A). The plantar opening of the foramen is slightly lateral to and near the midline and is positioned distal to the juncture of trochleae II and III (Fig. 3B). The fossa for the $\mathrm{m}$. supratrochlearis plantaris is shallow (Fig. 3B). Most of trochlea II is missing but appears to lack a well-defined plantar crest extending proximally from the ala of the trochlea (Fig. 3B). In distal view, trochlea II is plantarly deflected, and trochleae III and IV are widely spaced (Fig. 3E).

Comparison - A portion of a tarsometatarsus (MLP 90-I-20-9) recovered from Seymour Island was previously figured as gruiform but not described (Tambussi and Degrange, 2013: fig. 6.1g). This specimen comprises a distal diaphysis that is broken proximal to the trochleae, of which only the proximal-most part of trochlea IV is preserved. Despite the partial 
252 preservation, this fossil does not clearly show the splayed trochlear arrangement present in extant

253 Gruoidea (cranes, trumpeters and limpkins) and in TMM 44189-2. The lack of measurements or

254 description for MLP 90-I-20-9 make comparisons with the new fossil difficult, but as figured it

255 appears that this fossil is narrower than TMM 44189-2. Further evaluation is needed to

256 determine the exact relationship between the two fossils, but TMM 44189-2 exhibits a suite of

257 character states that allows for a more detailed assessment.

258 Phylogenetic studies that have recovered a monophyletic Gruiformes (sensu Hackett et

259 al., 2008) have not recovered synapomorphies from the distal tarsometatarsus that can be

260 assessed in this specimen see Mayr and Clarke, 2003; Musser and Cracraft, 2019; Musser et al.,

261 2019). However, TMM 44189-2 presents a combination of character states most consistent with

262 Gruiformes: (cranes, rails and allies): 1) trochleae III and IV projecting well distal of II; 2)

263 plantar deflection of trochlea II (as inferred from the base and preserved ala); 3) trochlea III

264 positioned dorsal to trochlea IV in distal view; 4) dorsoplantar flattening and mediolateral

265 broadening of the supratrochlear region; 5) position of the distal vascular foramen near the

266 midline and away from the lateral margin in plantar view; and 6) wide spacing of trochlea III and

267 IV. Within Gruiformes, TMM 44189-2 is more similar to Gruoidea than Ralloidea (rails, finfoots

268 and flufftails) based on the following characteristics: 1) trochlea II is not as plantarly deflected in

269 the new fossil as in ralloids; 2 ) trochlea II projects farther distally relative to III and IV in the

270 new fossil than in ralloids; 3) the distal vascular foramen is located midway between the midline

271 and the lateral margin in plantar view, unlike in ralloids where it is located on the midline; 4) the

272 supratrochlear region of the new fossil is mediolaterally broader and trochleae II and IV are more

273 widely spaced than in ralloids; 5) the distal margin of the distal vascular foramen is in line with

274 the proximal extent of trochlea III in dorsal view, unlike in ralloids; 6) the distal vascular 
275 foramen is located closer to the intertrochlear incisure in plantar view than in ralloids; and 7) in

276 dorsal view, the proximal extents of trochlea III and IV are subequal, whereas IV is proximal to

277 III in ralloids.

278 The morphology of TMM 44189-2 is not unambiguously consistent with any particular

279 gruoid subclade. Trochlea II is not as plantarly deflected as in Gruidae (cranes) or Aramus

280 guarauna (limpkin) and is more like the condition observed in Psophiidae (trumpeters). As in $A$.

281 guarana and Gruidae, trochlea III is the most dorsally positioned trochlea. There is a shallow

282 depression at the plantar base of trochlea IV along the beginning of an ala that is most like that of

283 B. pavonica and G. canadensis among compared Gruiformes. However, the trochlear bases of

284 TMM 44189-2 are not as dorsoventrally thick as those of $A$. guarana and Gruidae and are more

285 like those of Psophia viridis. The distal vascular foramen of TMM 44189-2 is ovoid in plantar

286 view, with the long axis at an oblique angle to the long axis of the shaft, as in Gruidae but unlike

287 A. guarauna and Psophia. In dorsal view, the distal vascular foramen is set in a broad, shallow

288 sulcus as in B. pavonica and Psophiidae; by contrast, this sulcus is deep and sharply defined in

289 Gruoidea. The fossil lacks the sharp plantar crest extending proximally from the ala of trochlea II

290 observed in Gruoidea. A marked, circular depression is located between trochleae II and III, and

291 is most like the condition in Psophia, A. guarana, and B. pavonica, although the observed depth

292 may be an artifact of preservation.

293

SPHENISCIFORMES Sharpe, 1891 sensu Clarke et al., 2003

295

Delphinornis sp.

296

(Fig. 4A-H)

297 
298 Material - TMM 44189-1, left tarsometatarsus.

299 Locality - S123, Seymour Island, Antarctic Peninsula.

300 Formation/Age - Submeseta Allomember I (TELM 7), Submeseta Formation, late Eocene.

301 Description - TMM 44189-1 (Fig. 4 A-D) is missing its proximal end and trochlea IV.

302 It is the more complete example of the two tarsometatarsi (including TMM 44188-2, described

303 below) recovered by the 2016 AP3 expedition that represent a small-bodied penguin. The

304 specimen is similar in size to the tarsometatarsus of the extant Spheniscus humboldti (Humboldt

305 Penguin). The hypotarsal crests are not preserved; however, an abraded surface appears to mark

306 the former distal-most extent of the medial hypotarsal crest. The medial proximal vascular

307 foramen is positioned directly medial to the abraded surface that potentially corresponds to the

308 medial hypotarsal crest. The distal vascular foramen is partially preserved, including a distinct

309 plantar foramen just lateral to the trochlea of metatarsal II

310 Comparison - TMM 44189-1 is referable to Sphenisciformes (penguins) based on its

311 overall proportions, morphology, and extreme osteosclerosis. The specimen possesses both

312 intertarsal grooves (Fig. 4A), unlike the much larger penguin tarsometatarsus described below

313 (TMM 44188-1). Although apparent, the medial intertarsal groove is shallower than that of all

314 comparable extant species. The lateral intertarsal groove is present and deep, similar to the

315 condition in extant species as well as the extinct taxa Delphinornis, Marambiornis, and

316 Mesetaornis (Myrcha et al., 2002; Jadwiszczak and Mörs, 2019). The groove does not taper

317 strongly distally, as in Marambiornis and Mesetaornis. The trochlea of metatarsal II is positioned

318 more medially than those of all comparable extant penguin species (Fig. 4A-B, D), resulting in a

319 wide medial intertrochlear incisure that appears most similar to that of Delphinornis (Myrcha et

320 al., 2002; Jadwiszczak and Mörs, 2019). A distal vascular foramen is present (Fig. 4A-B) as in 
321 taxa from the Paleocene of New Zealand, including Muriwaimanu, as well as the small Antarctic

322 taxa Delphinornis, Marambiornis, and Mesetaornis (Myrcha et al., 2002; Chávez Hoffmeister,

323 2014; Jadwiszczak, 2015; Jadwiszczak and Mörs, 2019). The distally-opening passage of the $\mathrm{m}$.

324 extensor brevis digiti IV is confluent with the distal vascular foramen (Fig. 4A), as in

325 Delphinornis, Marambiornis, and Mesetaornis (Myrcha et al., 2002; Hoffmeister, 2014;

326 Jadwiszczak, 2015; Jadwiszczak and Mörs, 2019). The plantar opening of the distal vascular

327 foramen is more distally positioned (Fig. 4B) than in Marambiornis and Mesetaornis and is

328 similar in morphology to that of Delphinornis (Myrcha et al., 2002; Jadwiszczak and Mörs,

329 2019). Based on these traits, we assign this fossil to Delphinornis. Tarsometatarsal traits that

330 distinguish among the three species of Delphinornis, namely morphology of the intercotylar

331 eminence, medial hypotarsal crest, proximal vascular foramina, and relative sizes of all three

332 trochleae (Myrcha et al., 2002), are not preserved in this specimen.

333

334 Material - TMM 44188-2, left tarsometatarsus.

335 Locality - S122, Seymour Island, Antarctic Peninsula. Fig. 1.

336 Formation/Age - Submeseta Allomember I (TELM 7), Submeseta Formation, late Eocene.

337 Description - TMM 44188-2 (Fig. 4E-H) is missing the proximal end and all three

338 trochleae. It is the less complete of the two 2016 specimens that represent a small penguin

339 morphotype. It is comparable in size to TMM 44189-1 and identical to that specimen in all

340 preserved morphologies. Therefore, it likely also represents a fragmentary specimen of the clade

341 Delphinornis.

342

Palaeeudyptes sp. 
346 Material - TMM 44188-1, left tarsometatarsus.

347 Locality - S117, Seymour Island, Antarctic Peninsula.

348 Formation/Age - Submeseta Allomember I (TELM 7), Submeseta Formation, late Eocene.

Description - TMM 44188-1 is a mostly complete tarsometatarsus that is missing trochlea IV (Fig. 4I-L). It has a proximodistal length of $45 \mathrm{~mm}$ and proximal mediolateral width of $39 \mathrm{~mm}$. The medial and lateral proximal cotyla are separated dorsally by a pronounced intercotylar eminence and plantarly by a planar intercotylar area. The medial proximal vascular foramen is positioned just distal to the distal terminus of the medial hypotarsal crest, and is less developed than the lateral proximal vascular foramen. A scar for the $\mathrm{m}$. tibialis cranialis is present on the dorsal face as a short ridge that extends distally from the proximal margin. The new tarsometatarsus lacks an appreciable medial dorsal intertarsal sulcus but exhibits a lateral 357 sulcus.

Comparison - TMM 44188-1 most closely resembles the tarsometatarsus of the contemporaneous Seymour Island penguin Palaeeudyptes gunnari based on the following features: 1) a concave medial margin, 2) a medial proximal vascular foramen that is larger than the lateral vascular foramen, 3) absence of an osseous ridge from the intermediate hypotarsal crest to the medial margin as in P. antarcticus (Myrcha et al., 2002), and 4) a proximally-

363 positioned scar for the $\mathrm{m}$. tibialis cranialis. The new specimen can be differentiated from the 364 contemporaneous and similarly sized Archaeospheniscus, known from Seymour Island and New Zealand, based on the lack of a medial dorsal intertarsal sulcus and unequally sized proximal vascular foramina (Simpson, 1971b; Myrcha et al., 2002). The new specimen is also distinct 
367 from the contemporaneous Anthropornis, known from Seymour Island and New Zealand, in

368 which the scar for the $\mathrm{m}$. tibialis cranialis is positioned more distally and the medial proximal

369 vascular foramen is larger than the lateral (Myrcha et al., 2002). Lastly, TMM 44188-1 is

370 significantly smaller than $P$. gunnari, P. klekowskii, and the two species of Palaeeudyptes known

371 from New Zealand, P. antarcticus and P. marplesi (Simpson, 1971a; Myrcha et al, 2002), and

372 may therefore represent a new species within Palaeeudyptes.

373

374

375

376

377

378

379

380

381

382

383

384

385

386

387

388

389
Gen. et sp. indet. C

(Fig. 4M-P)

Material - TMM 44187-1, rostral portion of mandible with associated caudal rami fragments.

Locality - S074, Seymour Island, Antarctic Peninsula.

Formation/Age - Cucullaea II (TELM 5), La Meseta Formation, late Eocene.

Description - TMM 44187-1 comprises the rostral end of a mandible that includes most of the symphyseal region, with the left mandibular ramus being more complete than the right (Fig. 4M-P). The rostralmost tip is missing. The preserved portion of the left ramus measures $171 \mathrm{~mm}$ in length and $7 \mathrm{~mm}$ in maximum width. An additional fragment of this ramus measures $81 \mathrm{~mm}$ in length, demonstrating that, when complete, the left mandibular ramus was at least 252 $\mathrm{mm}$. However, the articular regions of the mandible are missing, indicating that the original length of the bone was even greater. The preserved portion of the symphysis measures $37 \mathrm{~mm}$ in length and $10 \mathrm{~mm}$ wide at its rostrocaudal midpoint. We estimate the length of the complete symphysis at $40 \mathrm{~mm}$. The mandible is slender and pointed but sturdily constructed, and is excavated by vascular canals throughout much of its length. The tip of the mandible is straight, 
390 and the rami meet the symphysis along a straight line rather than at an angle. Mandibular fossae

391 are not preserved.

392 Comparison - Few penguin mandibles have been reported from Seymour Island, and to

393 date only one has been referable to a known species (MLP 14-XI-27-84 assigned to A. grandis;

394 Acosta Hospitaleche et al., 2019b). TMM 44187-1 has a shorter symphysial region than that

395 reported for MLP 14-XI-27-84 ( 45 mm), and lacks the ventrally convex, dorsally concave

396 condition seen in for $A$. grandis (Acosta Hospitaleche et al., 2019b). TMM 44187-1 differs from

397 other partial mandibles described from Seymour Island (MLP 91-II-4-221, MLP 92-II-2-195,

398 IB/P/B-0653; Jadwiszczak 2006; Acosta Hospitaleche and Haidr, 2011), which are more tapered

399 towards the distal end and have thinner rami. However, the overall morphology of the symphysis

400 is comparable to other Seymour Island fossils described despite differing in overall dimensions

401 (MLP 96-I-6-48, MLP 78-X-26-144, IB/P/B-0617e, MLP 14-XI-27-27; Jadwiszczak, 2006;

402 Acosta Hospitaleche and Haidr, 2011; Jadwiszczak, 2011; Haidr and Acosta Hospitaleche, 403 2017). The fossil MLP 96-I-6-48 has vascular pitting and a flattened dorsal surface similar to

404 those seen on TMM 44187-1 (Acosta Hospitaleche and Haidr, 2011), and the pitting is consistent 405 with the morphology of extant adult Aptenodytes forsteri (Emperor penguin; Sosa and Acosta 406 Hospitaleche, 2018). The shape of the rami of MLP 96-I-6-48, MLP 78-X-26-144, IB/P/B-167e, 407 and MLP 14-XI-27-27 are all similar to that of TMM 44187-1 (Acosta Hospitaleche and Haidr, 408 2011; Jadwiszczak, 2011, Haidr and Acosta Hospitaleche, 2017). An unassigned, mostly 409 complete mandible with associated maxilla most closely resembles the new fossil; MLP 14-XI410 27-27 appears to have similarly straight mandibular rami and appears to have a flattened dorsal 411 surface (Haidr and Acosta Hospitaleche, 2017: fig. 4b). However, only a dorsal view is figured 412 and the specimen lacks formal description, making it difficult to determine if the two fossils are 
413 from the same taxa. These fossils pertain to Paleogene penguins with spear- or dagger-like bills

414 characteristic of stem species (Slack et al., 2006; Clarke et al., 2007; Clarke et al. 2010; Ksepka

415 and Clarke, 2010; Jadwiszczak, 2011; Acosta Hospitaleche and Haidr 2012; Acosta Hospitaleche

416 et al., 2019b). However due to the new fossil's differences to assigned mandibular material

417 (Acosta Hospitaleche et al., 2019b) and its partial preservation, TMM 44187-1 is not considered

418 referable to any known Eocene taxa at this time.

\section{Discussion}

421

Though recently collected Eocene material is still fragmentary, it provides additional support for records of the presence of mammalian and avian taxa previously proposed from even more fragmentary and controversial single elements. These new records are also consistent with 424 those expected for the Eocene of Antarctica given longstanding hypotheses of a biotic connection between Antarctica and South America during the Paleogene as well as penecontemporaneous fossil discoveries from Patagonia (see Reguero et al., 2002; Sallaberry et al., 2010; Yury-Yáñez et al., 2012; Acosta Hospitaleche and Olivero, 2016; Reguero et al., 2014). The Eocene mammalian record otherwise comprises gondwanatheres, marsupials, cetaceans, 'South American native ungulates' (e.g., a litoptern, astrapotheres), and additional, enigmatic eutherians (Woodburne and Zinsmeister, 1984; Borsuk-Bialynicka, 1988; Case et al.,

431 1988; Bond et al., 1990; Hooker, 1992; Marenssi et al., 1994; Bargo and Reguero, 1998;

432 Fostowicz-Frelik, 2003; Reguero and Gasparini, 2006; Case, 2006; Reguero et al., 2013; Gelfo et 433 al., 2015; Buono et al. 2016; reviewed in Gelfo et al., 2019). Indeed, in addition to the described 434 metacarpal, the 2016 AP3 expedition recovered a vertebra (from locality S123) consistent with 435 referral to a basilosaurid archaeocete. Although new collections improve our understanding of 
436 biodiversity on Antarctica during the Eocene, they also highlight the need to recover and

437 describe more material to elucidate a nuanced understanding of biotic exchange during this key 438 time period.

439 Previous reports of xenarthrans from the Eocene of Seymour Island-based on a distal 440 ungual phalanx and an incomplete tooth —were initially assigned to Tardigrada (= Folivora)

441 (Marenssi et al., 1994; Vizcaíno and Scillato-Yané, 1995), but were later questioned (Bargo and 442 Reguero, 1998; MacPhee and Reguero, 2010). The phalanx was recovered from the Cucullaea I 443 Allomember, approximately $0.7 \mathrm{~km}$ away from where TMM 44290-I was collected, but lacks 444 formal description and has been reportedly lost, precluding reevaluation (Bargo and Reguero, 445 1998; figured in Gelfo et al., 2019: fig. 5b). It was noted to be indistinguishable from the earliest 446 known Vermilingua (anteaters) fossil from Patagonia, and based on histological study the tooth 447 was reassigned to Mammalia indet. (MacPhee and Reguero, 2010). Therefore, the newly 448 described specimen is either further evidence, or new evidence, that Xenarthra was indeed 449 present on Antarctica during the Eocene depending upon one's stance with reference to prior 450 controversies. This record is consistent with the estimated timing of origin for Folivora by the 451 Early Eocene, and of Xenarthra in the Paleocene (e.g., Presslee et al., 2019). Xenarthra is proposed to have originated in South America, and thus is plausibly 453 anticipated in the Paleogene of Antarctica given inferred land connections between these 454 continents during the early Cenozoic (Woodburne and Case, 1996; Delsuc et al., 2019; Presslee 455 et al., 2019). The new metacarpal extends the known Paleogene geographic range of Xenarthra 456 into Antarctica. Xenarthran limb bones and osteoderms have been reported from the early 457 Eocene (55-50 Ma) of Brazil (Gaudin and Croft, 2015; Superina and Loughry, 2015), but the 458 earliest reported members of Pilosa date to 31.5 Ma in Chile and Argentina (McKenna et al., 
459 2006; Gaudin and Croft, 2015) while described early cingulates from Patagonia are potentially

460 early Eocene (Marshall et al., 1983; Croft et al., 2007). If pilosan, the new material would

461 indicate that this clade was present in Antarctica by at least $35 \mathrm{Ma}$, four million years before it is

462 known in South America. A cingulate affinity would support the presence of the group in both

463 Antarctica and southern South America around the same time. However, the paucity of other

464 described Paleogene xenarthran postcranial material limits definitive analysis of the phylogenetic

465 affinities and ecology of this individual.

466 Antarctic bird fossils from non-penguins are rare, and only a few have been named as

467 species. They account for less than half of known extinct avian species diversity on the continent

468 (Tambussi and Acosta Hospitaleche, 2007; Tambussi and Degrange, 2013; reviewed in Acosta

469 Hospitaleche et al., 2019a), but comprise an even smaller fraction of unnamed material in

470 collections. Therefore, the distal tarsometatarsus, although fragmentary, expands our

471 understanding of Antarctic avian diversity during the late Eocene. A proposed gruiform from

472 Seymour Island was previously figured (Tambussi and Degrange, 2013: fig. 6.1g) but its relation

473 to the new fossil is difficult to assess. The new fossil exhibits preserved characters that allow for

474 a more confident referral to core-Gruiformes, providing new evidence for the presence of the

475 clade in Antarctica.

476 Our understanding of the paleobiogeography of Gruoidea remains incomplete due to a

477 near lack of known remains of Gruidae from the Paleogene of the Southern Hemisphere and of

478 reported parts of stem Aramidae and Psophiidea from the Paleogene (Mayr, 2009; Mayr, 2017;

479 Musser and Cracraft, 2019). Of these three clades, Gruidae has the most extensive fossil record,

480 with Eocene fossils primarily restricted to the Northern Hemisphere (e.g. Wetmore, 1933, 1940;

481 Cracraft 1969, 1973; Chandler and Wall, 2001; Clarke et al., 2005; Mayr, 2009; 2014; 2017). 
482 The new tarsometatarsus cannot confidently be referred to a subgroup within Gruoidea, and as

483 such has different biogeographic implications depending on its affinities. If more closely related

484 to Psophiidae or Aramidae, the new record suggests that these largely South American gruoid

485 families were more broadly distributed at least as far back as the late Eocene and supports

486 hypotheses of a distribution across Antarctic landmasses (Cracraft, 1982; Claramunt and

487 Cracraft, 2015; Musser and Cracraft, 2019). If placed within Gruidae, the new tarsometatarsus

488 could suggest that the gruid radiation may have been multi-directional; one radiation of cranes

489 could have dispersed from North America to Eurasia via the Bering Land Bridge during the early

490 Eocene and then dispersed towards west Eurasia over time (Claramunt and Cracraft, 2015), and

491 another radiation could have arrived in Antarctica by the late Eocene via South America.

492 However, more fossils are needed in order to gain a better understanding of the biogeography of

493 this group and core-Gruiformes as a whole within the Southern Hemisphere.

494 The penguin mandible described here adds to the record of spear-billed penguins reported

495 from the Eocene of Antarctica. Although fossil penguin cranial material is rare from Seymour

496 Island, two beak morphotypes are known: long and narrow, spear-like shapes (proposed to indicate

497 a primarily piscivorous diet) and shorter, broad morphs (proposed to indicate feeding on small

498 crustaceans; Ksepka and Clarke, 2010; Acosta Hospitaleche and Jadwiszczak, 2011; Haidr and

499 Acosta Hospitaleche, 2013, 2017; Acosta Hospitaleche et al., 2019b). The shape of the mandible

500 is consistent with a spear-billed morphology seen in other Antarctic remains (Acosta Hospitaleche

501 and Jadwiszczak, 2011; Haidr and Acosta Hospitaleche 2017, Acosta Hospitaleche et al., 2019b)

502 and similar to those of penecontemporaneous species from Peru (Perudyptes devriesi, mid-Eocene

503 [Clarke et al., 2007]; Icadyptes salasi, mid- to late-Eocene [Clarke et al., 2007; Ksepka et al.,

504 2008]) as well as Paleocene penguins from New Zealand (Muriwaimanu tuatahi; Sequiwaimanu 
505 rosieae: Slack et al., 2006; Ksepka and Clarke, 2010; Mayr et al., 2018). The morphology of the

506 mandible is consistent with the spear-billed morphology typical of stem species (Clarke et al.,

507 2007; Ksepka and Clarke, 2010; Haidr and Acosta Hospitaleche, 2013, 2017; Acosta Hospitaleche

508 et al., 2019b). Measurements of the symphysis and estimates of mandible length indicate that the

509 individual represented by the new mandible would have been larger than the older, New Zealand

510 species Muriwaimanu tuatahi (Slack et al., 2006) and between estimates reported for other Eocene

511 Antarctic spear-bills recovered from Seymour Islands (Acosta Hospitaleche and Jadwiszczak,

512 2011; Haidr and Acosta Hospitaleche, 2017; Acosta Hospitaleche et al., 2019b). The mandible

513 does not reach the maximum mandibular length recorded for the South American Icadyptes salasi

514 (Clarke et al., 2007), further supporting that a potential intermediate size class of these spear-billed

515 taxa was present on Antarctica.

516 Penguins were diverse across the globe during the Eocene, with 14+ species described

517 from Seymour Island alone (Jadwiszczak, 2006; Ksepka and Clarke, 2010; Acosta Hospitaleche,

5182013 and references therein; Jadwiszczak and Mörs, 2017; Jadwiszczak and Mörs, 2019;

519 reviewed in Acosta Hospitaleche et al., 2019). The materials described here add to our

520 understanding of this diversity with new material from a range of size classes: one large spear-

521 billed taxon, one medium-sized taxon represented by a tarsometatarsus, and small taxa

522 represented by two tarsometatarsi. It has been proposed that penguins were diverse in the mid- to 523 late Eocene in part because of the increasing productivity in the southern oceans (Diester-Haass

524 and Zahn, 1996; Clarke et al. 2007; Haidr and Acosta Hospitaleche, 2012; Villa et al., 2014). The

525 range of body sizes and bill morphotypes observed have also been hypothesized to be the result

526 of increased interspecific competition and size-based resource partitioning (Ksepka et al., 2008; 
527 Ksepka and Clarke, 2010; Haidr and Acosta Hospitaleche, 2012). The morphological diversity

528 reported here may lend further support to these hypotheses.

529

530 Conclusions

531 New records from Antarctica expand our understanding of the biodiversity on the continent

532 during the Eocene and support previously controversial reports of Gruiformes and Xenarthra. A

533 metacarpal is proposed to possibly represent a new early record of Cingulata or Folivora, and

534 lends support to previously reported xenarthran materials that have been subsequently questioned

535 or lost. The new tarsometatarsus supports the presence of Gruiformes in Antarctica during the

536 Eocene, adding to our understanding of the avian fossil record of Seymour Island. Newly

537 reported penguin remains, including a spear-shaped mandible and three tarsometatarsi, add to the

538 diversity of penguins known from this time. The nature of the Antarctic fossil record is

539 characterized by isolated elements and is dominated by penguins, making new discoveries vital

540 to furthering our understanding diversity during a period of climate change and tectonic shifts.

541 While historically fragmentary, new material from Antarctica is needed to elucidate trends in

542 biodiversity and biotic exchange during a key episode of Earth's history.

543

544 Acknowledgements

545 We gratefully acknowledge the assistance of all members of the Antarctic Peninsula

546 Paleontology Project (antarcticdinos.org) who participated in the 2016 field season. We are

547 indebted to S. Shelley, J. Wible, E. Amson, R. MacPhee, A. Kramarz, and M. Lorente for

548 comments on the mammalian material. We thank M. Brown and C. Sagebiel for curatorial

549 assistance and specimen access, D. Wagner for fossil preparation, V. De Pietri for photos of 
550 MLP 90-I-20-9, and P. O'Connor, L. English and H. McDonald for discussion and comments on

551 this work. We thank A. Farke, E. Amson and an anonymous reviewer for thorough and

552 constructive reviews that improved this manuscript.

553 
556 Acosta Hospitaleche, C. 2013. New crania from Seymour Island (Antarctica) shed light on anatomy of Eocene penguins. Polish Polar Research 34:397-412. DOI: $10.2478 /$ popore-2013-0018

Acosta Hospitaleche, C., Carabajal, A.P., Ruella, A., and Bauza, N. 2018. Anatomía craneal y reconstrucción paleoneurológica de Anthropornis Grandis Wiman (Aves, Sphenisciformes), del Eoceno de Antartida. Reunion de Comunicaciones de la

Acosta Hospitaleche, C., and J. N. Gelfo. 2017. Procellariiform remains and a new species from Acosta Hospitaleche, C., and J. N. Gelfo. 2015. New Antarctic findings of Upper Cretaceous and Asociación Paleontológica Argentina, Abstracts Volume. the latest Eocene of Antarctica. Historical Biology 29:755-769. DOI: $10.1080 / 08912963.2016 .1238470$

Acosta Hospitaleche, C., Jadwiszczak, P., Clarke, J. A., and Cenizo, M. 2019a. The fossil record of birds from the James Ross Basin, West Antarctica. Advances in Polar Science 30(3): 250-272. DOI: 10.13679/j.advps.2019.0014

Acosta Hospitaleche, C., and N. Haidr. 2011. Penguin cranial remains from the Eocene La Meseta Formation, Isla Marambio (Seymour Island), Antarctic Peninsula. Antarctic Science 23:369-378. DOI: 10.1017/S0954102011000216

575 Acosta Hospitaleche, C., Haidr, N., Paulina-Carabajal, A., and Reguero, M. 2019b. The first 
576

577

578

579

580

581

582

583

584

585

586

587

588

589

590

591

592

593

594

595

596

597

598

skull of Anthropornis grandis (Aves, Sphenisciformes) associated with postcranial elements. Comptes Rendus Palevol 18(6): 599-617. DOI: 10.1016/j.crpv.2019.06.003

Acosta Hospitaleche, C., and P. Jadwiszczak. 2011. Enigmatic morphological disparity in tarsometatarsi of giant penguins from the Eocene of Antarctica. Polish Polar Research 32:175-180. DOI: $10.2478 / \mathrm{v} 10183-011-0013-9$

Acosta Hospitaleche, C., and E. Olivero. 2016. Re-evaluation of the fossil penguin Palaeeudyptes gunnari from the Eocene Leticia Formation, Argentina: additional material, systematics, and palaeobiology. Alcheringa: An Australasian Journal of Palaeontology 40(3): 373-382. DOI: 10.1080/03115518.2016.1144994

Acosta Hospitaleche, C. 2014. New giant penguin bones from Antarctica: systematic and paleobiological significance. Comptes Rendus Palevol 13: 555-560. DOI: 10.1016/j.crpv.2014.03.008

Acosta Hospitaleche, C., and M. Reguero. 2014. Palaeeudyptes klekowskii, the best-preserved penguin skeleton from the Eocene-Oligocene of Antarctica: taxonomic and evolutionary remarks. Geobios 47:77-85. DOI: 10.1016/j.geobios.2014.03.003

Ali, J. R., and D. W. Krause. 2011. Late Cretaceous bioconnections between Indo-Madagascar and Antarctica: refutation of the Gunnerus Ridge causeway hypothesis. Journal of Biogeography 38:1855-1872. DOI: 10.1111/j.1365-2699.2011.02546.x

Amson, E., C. de Muizon, and T.J. Gaudin. 2017. A reappraisal of the phylogeny of the Megatheria (Mammalia: Tardigrada), with an emphasis on the relationships of the Thalassocninae, the marine sloths. Zoological Journal of the Linnean Society 179:217236. DOI: $10.1111 /$ zoj.12450

Amson, E., C. Argot, H.G. McDonald, and C. de Muizon. 2015. Osteology and functional 
morphology of the forelimb of the marine sloth Thalassocnus (Mammalia, Tardigrada). Journal of Mammalian Evolution 22:169-242. DOI: 10.1007/s10914-014-9268-3

601

602

603

604

605

606

607

608

609

610

611

612

613

614

615

616

Bargo, M. S., and M. A. Reguero. 1998. Annotated catalogue of the fossil vertebrates from Antarctica housed in the Museo de La Plata. I. Birds and land mammals from La Meseta Formation (Eocene-? early Oligocene); pp. 211-221, in S. Casadio, ed. Paleógeno de América del Sur y de la Península Antártica, vol. 5. Asociación Paleontológica Argentina, Publicación Especial.

Barker, P. F., B. Diekmann, and C. Escutia. 2007. Onset of Cenozoic Antarctic glaciation. Deep-Sea Research II 54:2293-2307. DOI: 10.1016/j.dsr2.2007.07.027

Beddard, F.E. 1902. “Mammalia”. London, Macmillan and Co., Limited. pp 169-175.

Birkenmajer, K., A. Gadźicki, K. Krajewski, A. Przybycin, A. Solecki, A. Tatur, and H. I. Yoon. 2004. First Cenozoic glaciers in West Antarctica. Polish Polar Research 26:3-12.

Bond, M., M. A. Reguero, and S. F. Vizcaíno. 2006. A new 'South American ungulate’ (Mammalia: Litopterna) from the Eocene of the Antarctic Peninsula; pp 163-176 in Cretaceous-Tertiary high-latitude palaeoenvironments, James Ross Basin, Antarctica. Special Publications, Geological Society of London. DOI: 10.1144/GSL.SP.2006.258.01.12

Bond, M., A. Kramarz, R. MacPhee, and M. Reguero. 2011. A new astrapothere (Mammalia, Meridiunugulata) from La Meseta Formation, Seymour (Marambio) Island, and a reassessment of previous records of Antarctic astrapotheres. American Museum Novitates 3718:1016.

Bond, M., R. Pascual, M. A. Reguero, S. H. Santillana, and S. A. Marenssi. 1990. Los primeros ungulados extinguidos sudamericanos de la Antártida. Ameghiniana 26:240. 
622 Borsuk-Bialynicka, M. 1988. New remains of Archaeoceti from the Paleogene of Antarctica. 623 Polish Polar Research 9:437-445.

624 Bowman, V., Ineson, J., Riding, J., Crame, J., Francis, J., Condon, D., Whittle, R., and 625 Ferraccioli, F. 2016. The Paleocene of Antarctica: dinoflagellate cyst biostratigraphy, 626 chronostratigraphy and implications for the palaeo-Pacific margin of Gondwana. Gondwana Research 38:132-148. DOI: 10.1016/j.gr.2015.10.018

Buono, M.R., Fernández, M.S., Reguero, M.A., Marenssi, S.A., Santillana, S.N. and Mörs, T., 629 2016. Eocene basilosaurid whales from the La Meseta Formation, Marambio (Seymour) Island, Antarctica. Ameghiniana, 53: 296-315. DOI: 10.5710/AMGH.02.02.2016.2922

Case, J. A. 2006. The late Middle Eocene terrestrial vertebrate fauna from Seymour Island: the tails of the Eocene Patagonian size distribution. Geological Society, London, Special Publications 258:177-186. DOI: 10.1144/GSL.SP.2006.258.01.13

Case, J., Woodburne, M.O., and Chaney, D. 1988. A new genus of polydolopid marsupial from Antarctica; In Feldmann, R. M. \& Woodbourne, M.O. eds. Geology and paleontology of Seymour Island, Antarctic Peninsula. Memoir of the Geological Society of America $169: 503-521$

Cenizo M. 2012. Review of the putative Phorusrhacidae from the Cretaceous and Paleogene of DOI: $10.1017 /$ jpa.2015.48 
646 Chornogubsky, L., Goin, F.J., and Reguero, M. 2009. A reassessment of Antarctic polydolopid marsupials (middle Eocene, La Meseta Formation). Antarctic Science 21(3): 285-297. DOI: $10.1017 / \mathrm{S} 0954102009001916$

649 Claramunt, S., and J. Cracraft. 2015. A new time tree reveals Earth history's imprint on the 650 evolution of modern birds. Science Advances 1:1-13. DOI: 10.1126/sciadv.1501005 651 Clarke, J.A., M.A. Norell, and D. Dashzeveg. 2005. New avian remains from the Eocene of Mongolia and the phylogenetic position of the Eogruidae (Aves, Gruoidea). American Museum Novitates 3494:1-17.

Clarke J.A., E. Olivero, and P. Puerta. 2003. Description of the earliest fossil penguin from

Clarke, J.A., D. T. Ksepka, M. Stucchi, M. Urbina, N. Giannini, S. Bertelli, Y. Narváez, and C. Boyd. 2007. Paleogene equatorial penguins challenge the proposed relationship between biogeography, diversity, and Cenozoic climate change. Proceedings of the National South America and first Paleogene vertebrate locality reported from Tierra del Fuego.

Cracraft, J. 1982. Phylogenetic relationships and transantarctic biogeography of some gruiform birds. Geobios 15: 393-402.

665 Croft, D.A., Flynn, J., and Wyss, A.R. 2007. A new basal glyptodontid and other Xenarthra of 666 667 the early Miocene Chucal fauna, northern Chile. Journal of Vertebrate Paleontology 27(4): 781-797. DOI: 10.1671/0272-4634(2007)27[781:ANBGAO]2.0.CO;2 
668 Cuadrelli, F., Zurita, A.E., Toriño, P., Miño-Boilini, A.R., Rodríguez-Bualó, S., Perea, D., and 669 Acuña Suárez, G.E. 2019. Late Pleistocene Glyptodontinae (Mammalia, Xenarthra, 670 Glyptodontidae) from southern South America: a comprehensive review. Journal of 671 Vertebrate Paleontology. DOI: 10.1080/02724634.2018.1525390.

672 Cuenca Anaya, J. 1995. El aparato locomotor de los escelidoterios (Edentata, Mammalia) y su 673 paleobiologia. Estudis, Adjuntament de Valencia 6:1-452.

674 De Iuliis, G., and Cartelle, C. 1994. The medial carpal and metacarpal elements of Eremotherium 675 and Meatherium (Xenarthra: Mammalia). Journal of Vertebrate Paleontology 13(4): 525533.

De Iuliis, G., and Cartelle, C. 1999. A new giant megatheriine ground sloth (Mammalia: Xenarthra: Megatheriidae) from the late Blancan to early Irvingtonian of Florida. Zoological Journal of the Linnean Society 127:495-515. DOI: 10.1006/zjls.1998.0190

De Iuliis, G., Pujos, F., Toledo, N., Susana, Bargo, S.M., and Vizcaíno, S.F. 2014. Eucholoeops Ameghino, 1887 (Xenarthra, Tardigrada, Megalonychidae) from the Santa Cruz Formation, Argentine Patagonia: implications for the systematics of Santacrucian sloths. Geodiversitas 36(2): 209-255. DOI: 10.5252/g2014n2a2

De Iuliis, T. J. Gaudin, and M. J. Vicars. 2011. A new genus and species of nothrotheriid sloth (Xenarthra, Tardigrada, Northrotheriidae) from the Late Miocene (Huayqierian) of Peru. Biology 29: 1-12. DOI: 10.1016/j.cub.2019.05.043 
691 Diester-Haass, L. and R. Zahn, 1996. Eocene-Oligocene transition in the Southern Ocean:

692 history of water mass circulation and biological productivity. Geology 24:163-166.

693 Eagles, G., and W. Jokat, 2014. Tectonic reconstructions for paleobathymetry in Drake Passage.

694 Tectonophysics 611:28-50. DOI: 10.1016/j.tecto.2013.11.021

695 Fernicola, J.C., Rinderknecht, A., Jones, W., Vizcaíno, S.F., and Porpino, K. 2018. A new species of Neoglyptatelus (Mammalia, Xenarthra, Cingulata) from the Late Miocene of Uruguay provides new insights on the evolution of the dorsal armor in cingulates.

698 Ameghiniana 55(3): 233-252. DOI: 10.5710/AMGH.02.12.2017.3150

699

Forasiepi, A.M., Sánchez-Villagra, M.R., Schmelzle, T., Ladevèze, S., and Kay, R.F. 2014. An exceptionally well-preserved skeleton of Palaeothentes from the Early Miocene of Patagonia, Argentina: new insights into the anatomy of extinct paucituberculatan marsupials. Swiss Journal of Paleontology.

Fostowicz-Frelik, L. 2003. An enigmatic whale tooth from the Upper Eocene of Seymour Island, 704 Antarctica. Polish Polar Research 24(1):13-28.

Gaudin, T. J., and D.A. Croft. 2015. Paleogene Xenarthra and the evolution of South American mammals. Journal of Mammalogy 96(4): 622-634. DOI: 10.1093/jmamma1/gyv073

Gelfo, J.N., Goin, F.J., Bauzá, N., and M. Reguero. 2019. The fossil record of Antarctic land mammals: commented review and hypotheses for future research. Advances in Polar Science 30(3): 274-292. DOI: 10.13679/j.advps.2019.0021

Gelfo, J. N., G. M. Lopez, and S. N. Santillana. 2017. Eocene ungulate mammals from West Antarctica: implications from their fossil record and a new species. Antarctic Science 29: 1-11. DOI: $10.1017 / \mathrm{S} 0954102017000244$

713 Gelfo, J. N., T. Mors, M. Lorente, G. M. López, and M. Reguero. 2015. The oldest mammals 
714

715

716

717

718

719

720

721

722

723

724

725

726

727

728

729

730

731

732

733

734

735

from Antarctica, Early Eocene of the La Meseta Formation, Seymour Island. Palaeontology 58:101-110. DOI: 10.1111/pala.12121

Gillette, D.D., and Ray, C.E. 1981. “Glyptodonts of North America”. Smithsonian Contributions to Paleobiology. pp 1-255. DOI: 10.5479/si.00810266.40.1

Goin F, Abello A, Bellosi E, Kay, R., Madden, R., and Carlini, A. 2007. Los Metatheria sudamericanos de comienzos del Neógeno (Mioceno Temprano, Edad-mamífero Colhuehuapense). Parte I: Introducción, Didelphimorphia y Sparassodonta. Ameghiniana 44(1): $29-71$.

Goin, F.J., and Carlini, A.A. 1995. An early Tertiary microbiotheriid marsupial from Antarctica. Journal of Vertebrate Paleontology 15(1): 205-207. DOI:

$$
10.1080 / 02724634.1995 .10011220
$$

Goin F.J., Case J.A., Woodburne M .O., Vizcaíno, S.F., and Reguero, M.A. 1999. New discoveries of "opposum-like" marsupials from Antarctica (Seymour Island, Medial Eocene). Journal of Mammalian Evolution 6(4): 335-365. DOI: 10.1023/A: 1027357927460 .

Goin, F. J., M. O. Woodburne, A. N. Zimicz, G. M. Martin, and L. Chornoqubsky. 2016. Dispersal of vertebrates from between the Americas, Antarctica, and Australia in the Late Cretaceous and Early Cenozoic; pp. 77-124 in A Brief History of South American Metatherians. Springer, Dordrecht. DOI: 10.1007/978-94-017-7420-8_3

Goin, F. J., M. A. Reguero, R. Pascual, W. Von Koenigswald, M. O. Woodburne, J. A. Case, C. - Vieytes, S. A., Marenssi, and S. F. Vizcaino. 2006. First gondwanatherian mammal from Antarctica; pp. 135-144 in Cretaceous-Teriary high-latitue palaeoenvironments, James 
736

737

738

739

740

741

742

743

744

745

746

747

748

749

750

751

752

753

754

755

756

757

758

Ross Basin, Antartica. Geological Society of London, Special Publications.

DOI: 10.1144/GSL.SP.2006.258.01.10

Goin F.J., Vieytes, E.C., Gelfo, J.N., Chornogubsky, L., Zimicz, A.N, and Reguero, M.A. 2018. New metatherian mammal from the Early Eocene of Antarctica. Journal of Mammalian Evolution 1-20. DOI: 10.1007/s10914-018-9449-6.

Hackett, S.J., Kimball, R.T., Reddy, S., Bowie, R.C.K., Braun, E.L., Braun, M.J., Chojnowski, J.L., Cox, W.A., Han, K., Harshman, J., Huddleston, C.J., Marks, B.D., Miglia, K.J., Moore, W.S., Sheldon, F.H., Steadman, D.W., Witt, C.C., and Yuri, T. 2008. A phylogenomic study of birds reveals their evolutionary history. Science, 320: 1763-1768. DOI: $10.1126 /$ science. 1157704

Haidr, N., and C. Acosta Hospitaleche. 2012. Feeding habits of Antarctic Eocene penguins from a morpho-functional perspective. Neues Jahrbuch für Geologie und Paläontologie Abhandlungen 263:125-131. DOI: 10.1127/0077-7749/2012/0217

Haidr, N., and C. Acosta Hospitaleche. 2017. Fossil penguin beaks from the Eocene of Antarctica: new materials from La Meseta Formation. Museo Argentino de Ciencias Naturales "Bernardino Rivadavia".

Haro, J. A., A. A. Tauber, and J. M. Krapovickas. 2017. Thoracic member (pectoral girdle and forelimb) bones of Mylodon darwinii Owen (Xenarthra, Mylodontidae) from the Late Pleistocene of Central Argentina and their phylogenetic implications. Paläontologische Zeitschrift 91:439-457. DOI: 10.1007/s12542-017-0350-z

Scott, W.B. 1903-1905. Mammalia of the Santa Cruz beds. Part 1 and 2. In Scott, W.B. (ed.) "Reports of the Princeton University Expeditions to Patagonia, 1896-1899". Princeton University, Vol. 5 pp 99. 
759 Hoffmeister, C. 2014. Phylogenetic characters in the humerus and tarsometatarsus of penguins.

760 Polish Polar Research 35:469-496. DOI: 10.2478/popore-2014-0025

761 Hooker, J. J. 1992. An additional record of a placental mammal (Order Astrapotheria) from the

762 Eocene of West Antarctica. Antarctic Science 4:107-108.

763 Ivany, L. C., S. Van Simaeys, E. W. Domack, and S. D. Samson. 2006. Evidence for an earliest

764 Oligocene ice sheet on the Antarctic Peninsula. Geology 34:377-380. DOI:

765 $10.1130 / \mathrm{G} 22383.1$

766

767

768

769

770

771

772

773

774

775

776

777

778

779

780

781

Ivany, L. C., T. Brey, M. Huber, D. P. Buick, and B. R. Schöne. 2011. El Niño in the Eocene greenhouse recorded by fossil bivalves and wood from Antarctica. Geophysical Research Letters 38:1-6. DOI: 10.1029/2011GL048635

Jacques, F. M. B., G. Shi, H. Li, and W. Wang. 2014. An early-middle Eocene Antarctic summer monsoon: evidence of "fossil climates". Gondwana Research 25:1422-1428. DOI: 10.1016/j.gr.2012.08.007

Jadwiszczak, P. 2006. Eocene penguins of Seymour Island, Antarctica: Taxonomy. Polish Polar Research 27(1):3-62.

Jadwiszczak, P. 2011. Short note: new data on morphology of late Eocene penguins and implications for their geographic distribution. Antarctic Science 23(6):605-606. DOI: $\underline{10.1017 / S 0954102011000526}$

Jadwiszczak, P. 2015. Another look at tarsometatarsi of early penguins. Polish Polar Research 36:343-354. DOI:10.1515/popore-2015-0024

Jadwiszczak P, and Mörs T. 2017. An enigmatic fossil penguin from the Eocene of Antarctica. Polar Research, 36. DOI: 10.1080/17518369.2017.1291086

Jadwiszczak, P., A. J. Gazdicki, and A. Tatur. 2008. Short note: an ibis-like bird from the Upper 

20(4):413-414. DOI: 10.1017/S0954102008000977

784

785

786

787

788

789

790

791

792

793

794

795

796

797

798

799

800

801

802

803

804

Jadwiszczak, P., and T. Mörs. 2019. First partial skeleton of Delphinornis larseni Wiman, 1905, a slender-footed penguin from the Eocene of Antarctic Peninsula. Paleontologia Electronica, 22.2.32A 1-31. DOI: 10.26879/933

Keast, A. 1972. Introduction: The southern continents as backgrounds for mammalian evolution; pp. 19-22, in A. Keast, F. C. Erk, and B. Glass, eds. Evolution, Mammals, and Southern Continents. State University of New York Press, Albany.

Ksepka, D.T., and S. Bertelli. 2006. Fossil penguin (Aves: Sphenisciformes) cranial material from the Eocene of Seymour Island (Antarctica). Historical Biology, 18(4):389-395. DOI: $10.1080 / 08912960600658376$

Ksepka, D. T., and J. A. Clarke. 2010. The basal penguin (Aves: Sphenisciformes) Perudyptes devriesi and a phylogenetic evaluation of the penguin fossil record. Bulletin of the American Museum of Natural History 337:1-77.

Ksepka, D. T., J. A. Clarke, T. J. DeVries, and M. Urbina. 2008. Osteology of Icadyptes salasi, a giant penguin from the Eocene of Peru. Journal of Anatomy 213:131-147. DOI: 10.1111/j.1469-7580.2008.00927.x.

Lydekker, R. 1891. Catalogue of the fossil birds in the British Museum (Natural History). British Museum (Natural History), London.

MacPhee, R. D. E. and M. A. Reguero. 2010. Reinterpretation of a Middle Eocene record of Tardigrada (Pilosa, Xenarthra, Mammalia) from La Meseta Formation, Seymour Island, West Antarctica. American Museum Novitates 3689:1-21.

Marenssi, S. A. 2006. Eustatically controlled sedimentation recorded by Eocene strata of the 
805

806

807

808

809

810

811

812

813

814

815

816

817

818

819

820

821

822

823

824

825

826

827

James Ross Basin, Antarctica. Geological Society, London, Special Publications 258:125-133. DOI: 10.1144/GSL.SP.2006.258.01.09

Marenssi, S. A., L. I. Net, and S. N. Santillana. 2002. Provenance, environmental and paleogeographical controls on sandstone composition in an incised-valley system: the Eocene La Meseta Formation, Seymour Island, Antarctica. Sedimentary Geology 150: 301-321. DOI: 10.1016/S0037-0738(01)00201-9

Marenssi, S. A., S. N. Santillana, and C. A. Rinaldi, 1998. Stratigraphy of La Meseta Formation (Eocene), Marambio Island, Antarctica; pp. 137-146, in S. Casadío, ed. Paleógeno de América del Sur y de la Península Antártica, vol. 5. Asociación Paleontológica Argentina, Publicación Especial.

Marenssi, S. A., M. A. Reguero, S. N. Santillana, and S. F. Vizcaíno. 1994. Eocene land mammals from Seymour Island, Antarctica: palaeobiogeographical implications. Antarctic Science 6:3-15.

Marshall, L. G., Hoffstetter, R., and Pascual, R. 1983. Mammals and stratigraphy: geochronology of the mammal-bearing Tertiary of South America. Palaeovertebrata, Mémoire Extraordinaire 1983: 1-93.

Martinelli, A., Chornogubsky, L., Abello, M., Goin, F., and Reguero, M. 2014. The first nontherian dryolestoid from Antarctica. SCAR Open Science Conference, Auckland, New Zealand, Volume: Abstracts Volume. DOI: 10.13140/2.1.2770.8805.

Mayr, G. 2009. Paleogene Fossil Birds. Springer Berlin Heidelberg.

Mayr, G., and J. A. Clarke. 2003. The deep divergences of neornithine birds: a phylogenetic analysis of morphological characters. Cladistics 19: 527-553. DOI: 10.1111/j.10960031.2003.tb00387.x 
828 Mayr, G., R. P. Scofield, V. L. De Pietri, and A. J. D. Tennyson. 2017. A Paleocene penguin

829 from New Zealand substantiates multiple origins of gigantism in fossil Sphenisciformes.

$830 \quad$ Nature Communications. 8:1-8. DOI: 10.1038/s41467-017-01959-6

831 Mayr, G., V. L. Pietri, A. A. Mannering, and R. P. Scofield. 2018. A well-preserved new mid-

832 Paleocene penguin (Aves, Sphenisciformes) from the Waipara Greensand in New

833 Zealand. Journal of Vertebrate Paleontology 37. DOI: 10.1080/02724634.2017.1398169

834 McDonald, H.G., Vizcaíno, S.F., and Bargo, M.S. 2008. "Skeletal anatomy and the fossil history

835 of the Vermilingua”. In Vizcaíno, S.F., Loughry, W.J. (eds.). The Biology of the

$836 \quad$ Xenarthra. pp 64-72.

837 McKenna, M. C., A. R. Wyss, and J. J. Flynn. 2006. Paleogene pseudoglyptodont xenarthrans

838 from Central Chile and Central Patagonia. American Museum Novitates 3536:1-18.

839 Musser, G. M., D. T. Ksepka, and D. J. Field. 2019. New Material of Paleocene-Eocene Pellornis

840 (Aves: Gruiformes) Clarifies the Pattern and Timing of the Extant Gruiform Radiation.

841 Diversity 11. DOI: $10.3390 / \mathrm{d} 11070102$

842 Musser, G. M., and J. Cracraft. 2019. A new morphological dataset reveals a novel

843 relationship for the Adzebill of New Zealand (Aptornis) and provides a foundation total

844 evidence neoavian phylogenetics. American Museum Novitates 3927: 1-70.

845 Myrcha, A., P. Jadwiszczak, C. P. Tambussi, J. I. Noriega, A. Gaździcki, A. Tatur, and R. A. Del

846 Valle. 2002. Taxonomic revision of Eocene Antarctic penguins based on tarsometatarsal

847 morphology. Polish Polar Research 23:5-46.

848 Orr, C.M. 2005. Knuckle-walking anteater: A convergence test of adaptation for purported

849 knuckle-walking features of African Hominidae. American Journal of Physical

$850 \quad$ Anthropology 128: 639-658. DOI: 10.1002/ajpa.20192 
851 Owen, R. 1842. Description of the skeleton of an extinct gigantic sloth, Mylodon robustus,

852 Owen, with observations on the osteology, natural affinities, and probable habits of the 853 megatherioid quadrupeds in general. London: Royal College of Surgeons of England, 1$854 \quad 176$.

855 Poole, I., R. J. Hunt, and D. J. Cantrill. 2001. A fossil wood flora from King George Island: 856 ecological implications for Antarctic Eocene vegetation. Annals of Botany 88:35-54. DOI: $10.1006 /$ anbo.2001.1425

Presslee, S., G. J. Slater, F. Pujos, A.M. Forasiepi, R. Fischer, K. Molloy, M. Mackie, J.V. Olsen, A. Kramerz, M. Taglioretti, F. Scaglia, M. Lezcano, J.L. Lanata, J. Southon, R. Feranec, J. Bloch, A. Hajkuk, F.M. Martin, R.S. Gismodni, M. Reguero, C. de Muizon, A. Greenwood, B.T. Chait, K. Penkman, M. Collins, and R.D.E. MacPhee. 2019. Palaeoproteomics resolves sloth relationships. Nature Ecology and Evolution. DOI: 10.1038/s41559-019-0909-Z

Pujos, F., and R. Salas. 2004. A new species of Megatherium (Mammalia: Xenarthra: Megatheriidae) from the Pleistocene of Sacaco and Tres Ventanas, Peru. Palaeontology 47:579-604. DOI: 10.1111/j.0031-0239.2004.00376.x

Reguero, M., and Z. Gasparini. 2006. Late Cretaceous - Early Tertiary marine and terrestrial vertebrates from James Ross Basin, Antarctic Peninsula: A review; pp. 55-76, in J. Rabassa and M. L. Borla, eds. Antarctic Peninsula and Tierra del Fuego: 100 Years of Swedish-Argentine Scientific Cooperation at the End of the World. Taylor \& Francis,

872 Reguero, M. A., S. A. Marenssi, and S. N. Santillana. 2002. Antarctic Peninsula and South 
873

874

875

876

877

878

879

880

881

882

883

884

885

886

887

888

889

890

891

892

893

894 895

America (Patagonia) Paleogene terrestrial faunas and environments: biogeographic relationships. Palaeogeography, Palaeoclimatology, Palaeoecology 179:189-210. DOI: 10.1016/S0031-0182(01)00417-5

Reguero, M. A., J. N. Gelfo, G. M. López, M. Bond, A. Abello, S. N. Santillana, and S. A. Marenssi. 2014. Final Gondwana breakup: The Paleogene South American native ungulates and the demise of the South America-Antarctica land connection. Global and Planetary Change 123:400-413. DOI: 10.1016/j.gloplacha.2014.07.016

Sadler, P.M. 1988. Geometry and stratification of uppermost Cretaceous and Paleogene units on Seymour Island, northern Antarctic Peninsula. In: Feldmann R.M., Woodburne, MO., editors. Geology and paleontology of Seymour Island, Antarctic Peninsula. Geological Society of America Memoir.

Sallaberry, M.A., Yury-Yáñez, R.E., Otero, R.A., Soto-Acuña, S., and Torres, T.G. 2010. Eocene birds from the western margin of southernmost South America. Journal of Paleontology 84(6): 1061-1070. DOI: 10.1666/09-157.1

Scott, W.B. 1909. Mammalia of the Santa Cruz beds. Part IV. Astrapotheria. Reports of the Princeton University Expeditions to Patagonia 6: 301-351.

Scott, W.B. 1937. The Astrapotheria. Proceedings of the American Philosophical Society 77: 309-393.

Shockey, B.J., and Flynn, J.J. 2007. Morphological diversity in the postcranial skeleton of Casamayoran (?Middle to Late Eocene) Notoungulata and foot posture in Notoungulates. American Museum Novitates, 3601:1-26.

Simpson, G. G. 1971a. A review of the Pre-Pliocene penguins of New Zealand. Bulletin of the American Museum of Natural History 144:319-378 
896 Simpson, G. G. 1971b. Review of fossil penguins from Seymour Island. Proceedings of the $897 \quad$ Royal Society of London B: Biological Sciences 178:357-387.

898 Slack, K. E., C. M. Jones, A. Tatsuro, G. L. Harrison, R. E. Fordyce, U. Arnason, and D. Penny. 899 2006. Early penguin fossils, plus mitochondrial genomes, calibrate avian evolution. $900 \quad$ Molecular Biology and Evolution 23:1144-1155. DOI: 10.1093/molbev/msj124

901 Sosa, M.A. and C. Acosta Hospitaleche. 2018. Ontogenetic variation of the head of Aptenodytes 902 foresteri (Aves, Sphenisciformes): muscular and skull morphology. Polar Biology

903 41:225-235. DOI: $10.1007 / \mathrm{s} 00300-017-2183-3$

904

905

906

907

908

909

910

911

912

913

914

915

916

917 Torsvik, T. H., and L. R. M. Cocks. 2013. Gondwana from top to base in space and time.

918

Stock, C. 1925. Cenozoic gravigrade edentates of western North America with special reference to the Pleistocene Megalonychinae and Mylodontidae of Rancho La Brea. Carnegie Institution of Washington Publication 331:1-206.

Superina, M., and W. J. Loughry. 2015. Why do xenarthrans matter? Journal of Mammalogy 96(4):617-621. DOI: 10.1093/jmammal/gyv099

Tambussi, C., and C. Acosta Hospitaleche. 2007. Antarctic birds (Neornithes) during the Cretaceous-Eocene times. Revista de la Asociación Geológica Argentina 62:604-617.

Tambussi, C. P., and F. J. Degrange. 2013. South American and Antarctic Continental Cenozoic Birds. Springer: Dordrecht p.53.

Tambussi, C. P., C. I. Acosta Hospitaleche, M. A. Reguero, and S. A. Marenssi. 2006. Late Eocene penguins from West Antarctica: systematics and biostratigraphy. Geological Society, London, Special Publications 258:145-161. DOI: 10.1144/GSL.SP.2006.258.01.11 
919 Villa, G., C. Fioroni, and D. Persico. 2014. Middle Eocene to Late Oligocene Antarctic

920 glaciation/deglaciation and Southern Ocean productivity. Paleoceanography 29:223-237.

921 DOI: $10.1002 / 2013$ PA002518

922 Vizcaíno, S. F., and G. J. Scillato-Yané. 1995. An Eocene tardigrade (Mammalia, Xenarthra)

923 from Seymour Island, West Antarctica. Antarctic Science 7:407-408.

924 Woodburne, M. O., and Case, J. A. 1996. Dispersal, vicariance, and the Late Cretaceous to early 925 Tertiary land mammal biogeography from South America to Australia. Journal of

926 Mammalian Evolution 3(2):121-161.

927 Woodburne, M. O., and W. J. Zinsmeister. 1984. The first land mammal from Antarctica and its 928 biogeographic implications. Journal of Paleontology 58:913-948.

929 Yury-Yáñez, R.E., Otero, R.A., Soto-Acuña, S., Suárez, M.E., Rubilar-Rogers, D., and 930 Sallaberry, M. 2012. First bird remains from the Eocene of Algarrobo, central Chile.

931 Andean Geology 39(3): 548-557. DOI: 10.5027/andgeoV39n3-a10

932 Zachos, J., M. Pagani, L. Sloan, E. Thomas, and K. Billups. 2001. Trends, rhythms, and 933 aberrations in global climate 65 Ma to present. Science 292:686-693. DOI:

$934 \quad 10.1126 /$ science. 1059412

935 Zinsmeister, W. J. 1986. Fossil windfall at Antarctica's edge. Natural History 95:60-67. 


\section{Figure 1}

Map and geology of Seymour Island, James Ross Basin, Antarctic Peninsula, showing the localities where new material was recovered.

Fossil localities are marked by dots in the La Meseta and Submeseta Formations. The mammalian metacarpal was recovered from S124, the penguin mandible from S074, and the three tarsometatarsi from S123 and S117/122. Modified from Montes et al. (2013).

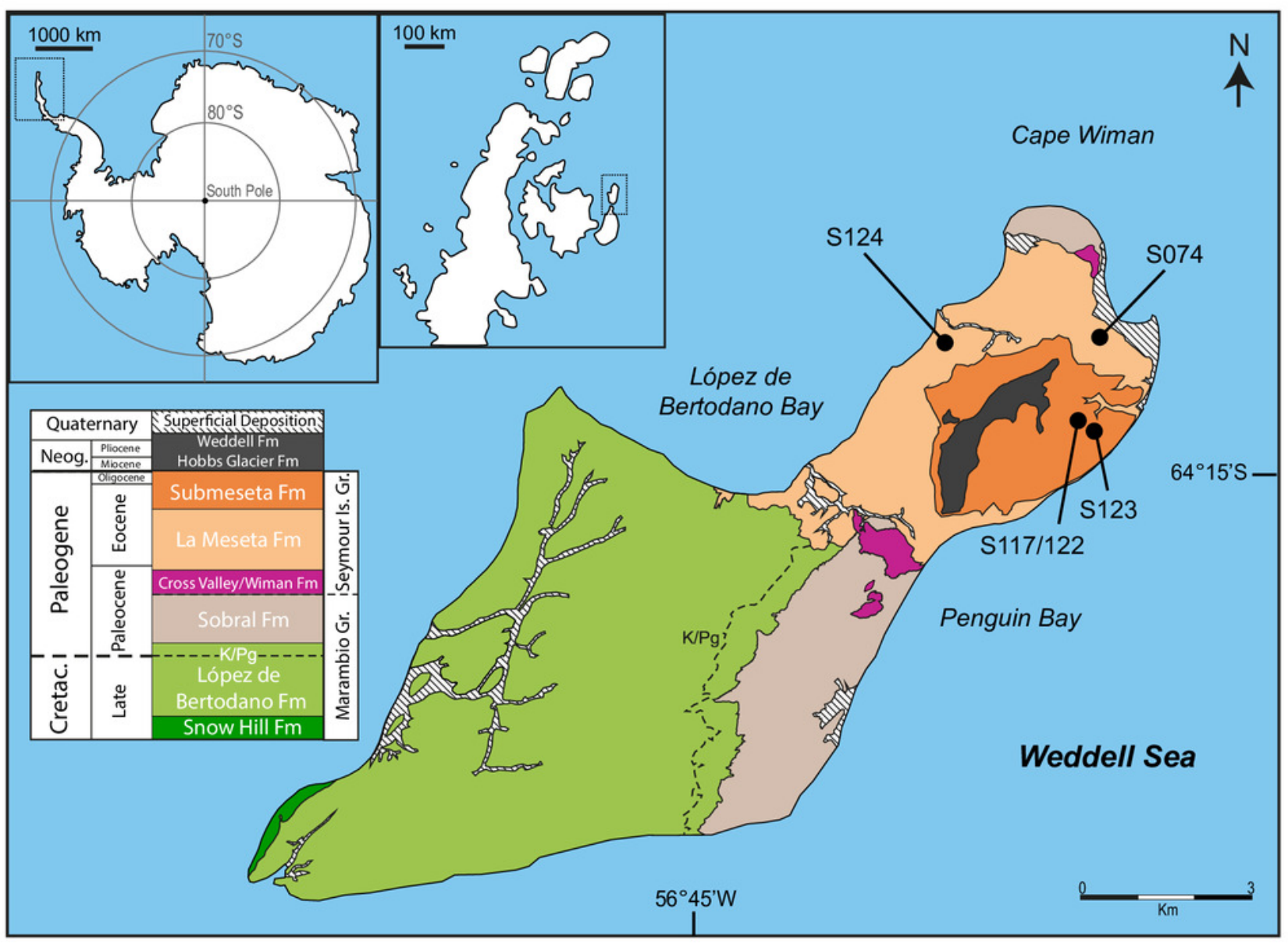




\section{Figure 2}

Left metacarpal II (TMM 44190-1) referred to Xenarthra.

(A) lateral; (B) medial; (C) palmar; (D) dorsal; (E) proximal; and (F) distal views. Features are tentatively indicated, as they are difficult to assign given the isolated and fragmentary nature of the element. Abbreviations: ?mcc, facet for either the metacarpal-carpal complex or for metacarpal I; $\mathbf{m c l I I}$, facet for metacarpal III; $\mathbf{t}$, trapezoid facet. Scale bar $=10 \mathrm{~mm}$. 

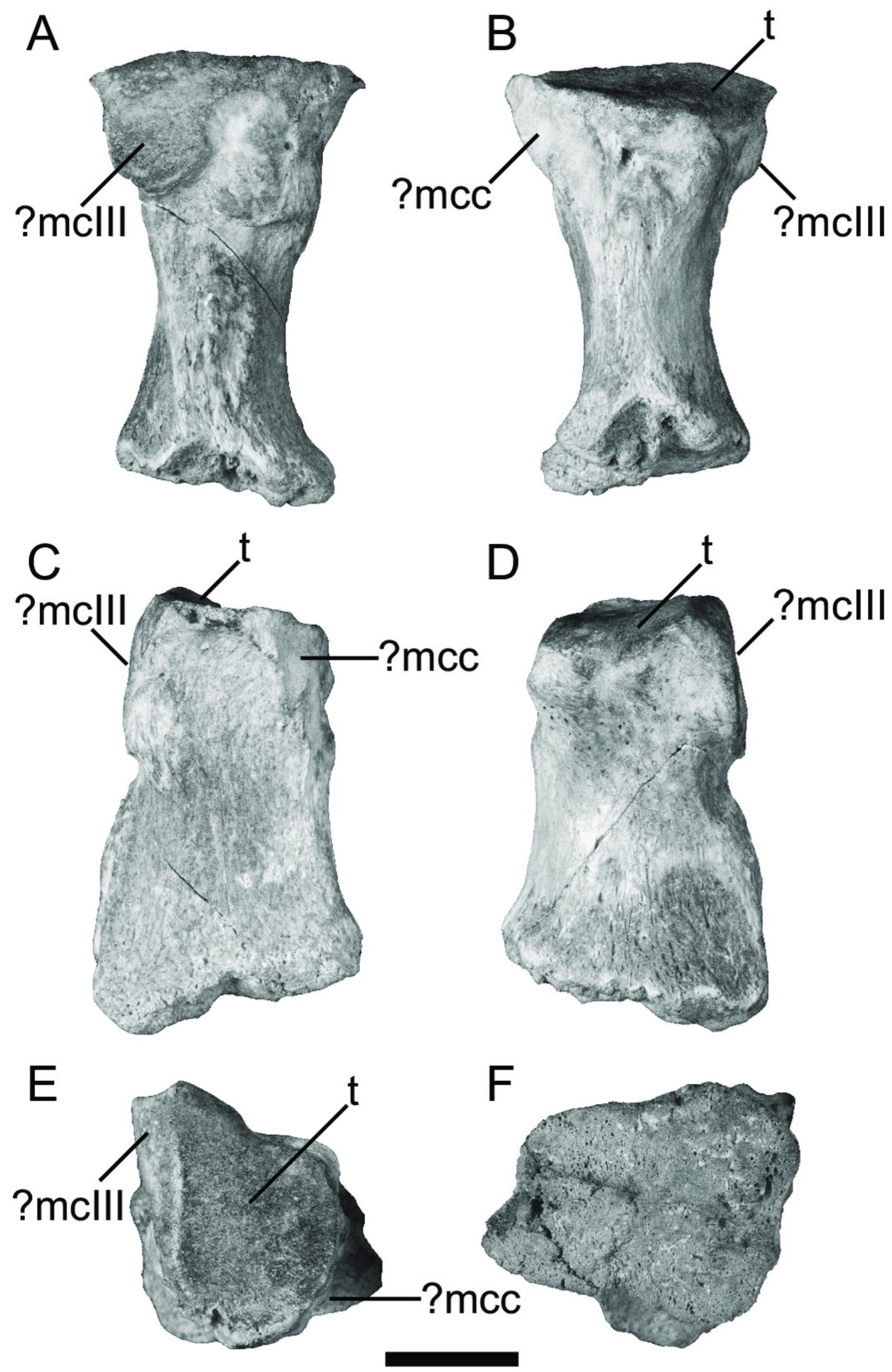
Figure 3

Distal end of a left tarsometatarsus (TMM 44189-2) compared to those of extant gruiforms.

The fossil (A-E) and comparative materials (F-Y) shown in dorsal, plantar, medial, lateral, and distal views. Abbreviations: II, trochlea II; III, trochlea III; IV, trochlea IV; dvf, distal vascular foramen. Scale bar $=10 \mathrm{~mm}$. 
TMM 44189-2

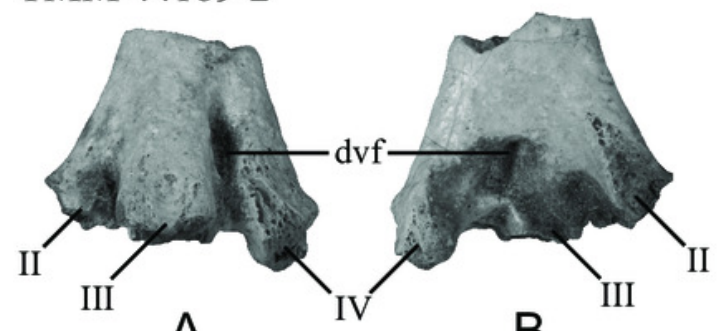

Balearica pavonica

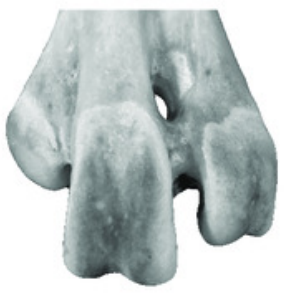

F

Grus canadensis

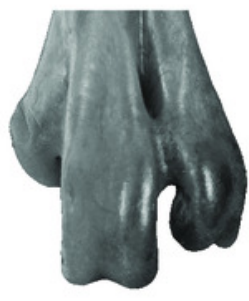

$\mathrm{K}$

Psophia viridis

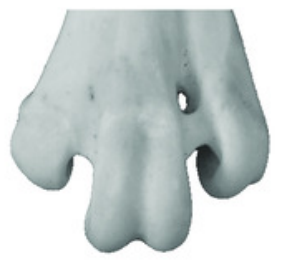

$\mathrm{P}$

Rallus longirostris

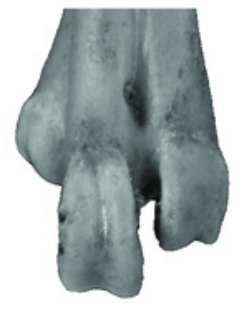

U

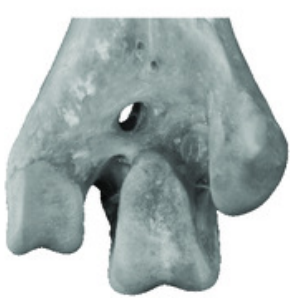

G

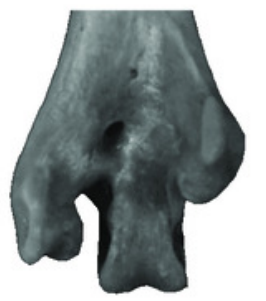

L

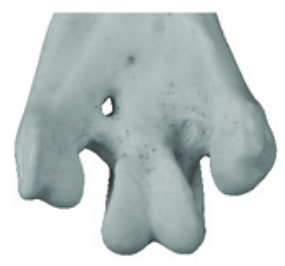

Q

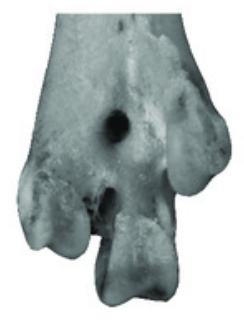

V

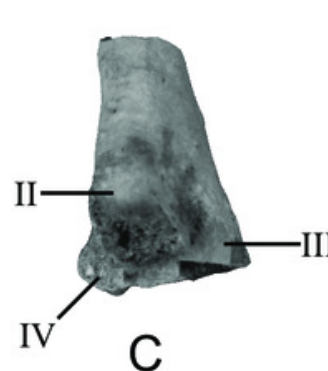

C

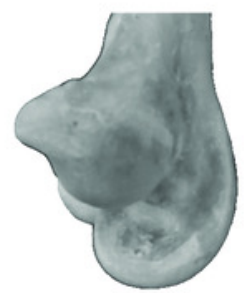

$\mathrm{H}$

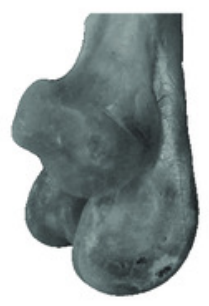

M

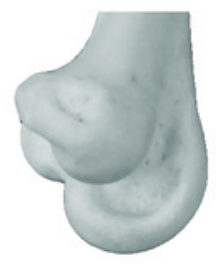

$\mathrm{R}$

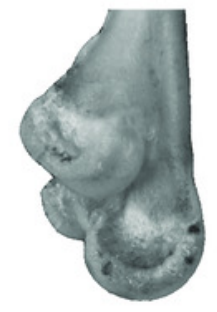

W

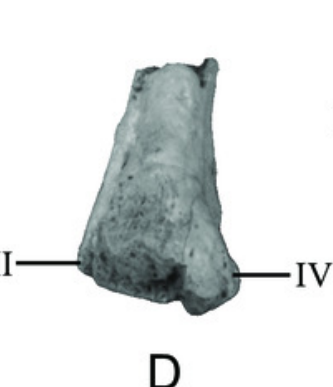

D

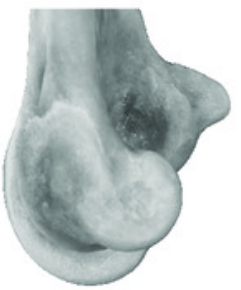

I

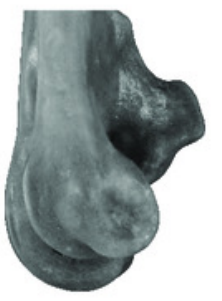

$\mathrm{N}$

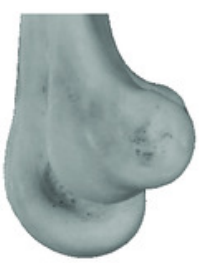

$\mathrm{S}$

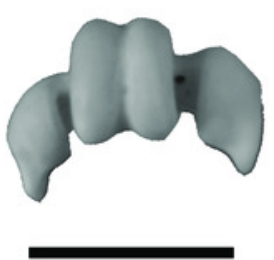

T

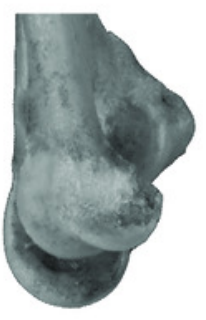

$\mathrm{X}$
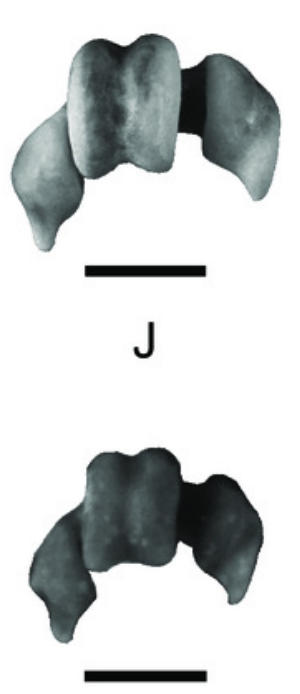

O

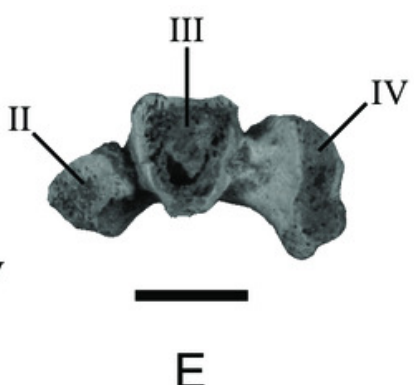

E

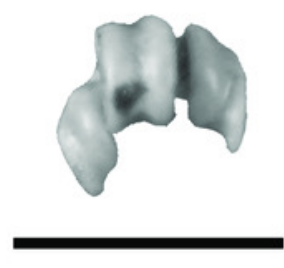

Y 


\section{Figure 4}

New sphenisciform fossil material.

A small left tarsometatarsus (TMM 44189-1) in (A) dorsal, (B) plantar, (C) proximal, and (D) distal views; a small left tarsometatarsus (TMM 44188-2) in (E) dorsal, (F) plantar, (G) proximal and (H) distal views; a large left tarsometatarsus (TMM 44188-1) in (I) dorsal, (J) plantar, (K) proximal, and (L) distal views; and a partial mandible (TMM 44187-1) in (M) dorsal, (N) ventral, $(\mathbf{O})$ right (with associated material), and $(\mathbf{P})$ left (with associated material) views. Abbreviations: II, trochlea II; III, trochlea III; dvf, distal vascular foramen; es, extensor sulcus; fs, flexor sulcus; $\mathbf{h}$, hypotarsus; ia, intercotylar area; ie, intercotylar eminence; Ic, lateral cotyla; mc, medial cotyla; ms, mandibular symphysis; pvf, proximal vascular foramen. Scale bar $=10 \mathrm{~mm}$. 

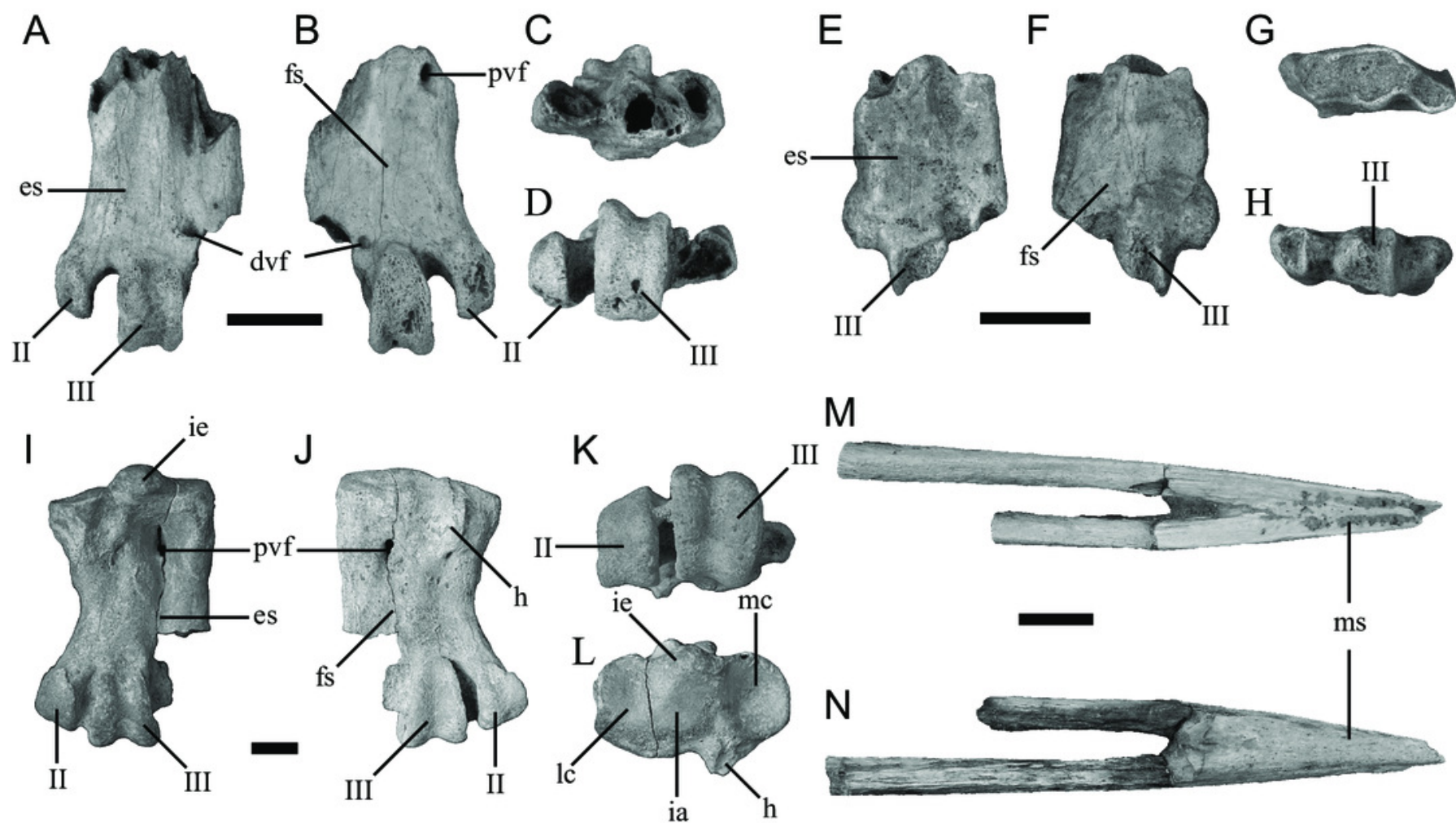

0
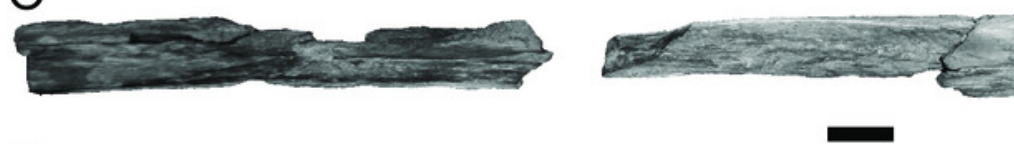

N

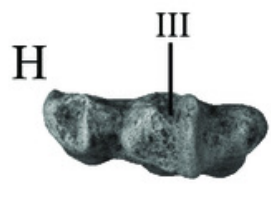

P
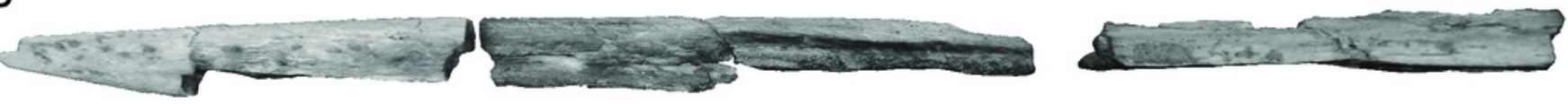